\title{
Genetic analysis for various yield components and gluten content in bread wheat (Triticum aestivum L.)
}

\author{
Sandeep Kumar ${ }^{1}$, Pradeep Kumar ${ }^{2 *}$ and S. A. Kerkhi ${ }^{1}$ \\ ${ }^{1}$ Sardar Vallabhbhai Patel University of Agriculture and Technology, Meerut, 250110 (UP), INDIA \\ ${ }^{2}$ Indian Institute of Wheat and Barley Research, Karnal, 132001 (Haryana), INDIA \\ *Corresponding authors: E-mail:pradeeptaliyan231@gmail.com \\ Received: August 22, 2016; Revised received: February 9, 2017; Accepted: April 28, 2017
}

\begin{abstract}
Genetic analysis was carried out in 55 genotypes (10 parents and $45 F_{1} s$ ) through diallel mating design excluding reciprocals in bread wheat (Triticum aestivum L.). Analysis of variance showed wide range of variability among the breeding material for all the traits under study. The highest value of phenotypic coefficient of variation (PCV) and genotypic coefficient of variation (GCV) were recorded for grain yield (PCV=9.07 and GCV= 8.08). Highest heritability with genetic advance was recorded for grain yield $\left(h^{2}=10.60\right.$ and $\left.G A=14.84\right)$, therefore selection will be effective based on grain yield for further study. Grains per spike ( $\mathrm{gr}=0.77$ and $\mathrm{pr}=0.67$ ) and spikelets per spike ( $g r=0.63$ and $\mathrm{pr}=0.52$ ) were found significantly correlated (at $<1 \%$ level of significance) with grain yield whereas gluten content showed nonsignificant but positive correlation with grain yield at both genotypic as well as phenotypic level. Similarly, path coefficient analysis estimates for gluten content $(g=0.08$ and $p=0.03)$ and grains per spike ( $g=0.36$ and $p=0.23$ ) showed high positive direct effects on grain yield therefore these traits may be used as an index for selection to high yield in bread wheat genotypes.
\end{abstract}

Keywords: Correlation, Diallel analysis, Yield traits, Gluten content, Triticum aestivum

\section{INTRODUCTION}

Bread wheat (Triticum aestivum L.) is an important cereal crop in India and play an important role in food security. India holds second position in both area and production after china and also planted to an area of 30.23 million hectares with production amounting to 93.50 million tons (Anonymous 2016) in India. Genetic analysis of wheat yield improvement had shown that grain yield is determined by different component traits, therefore, the knowledge of selection parameters and eye judgment of the breeder will apply after creation of genetic variability. Diallel analysis is most effective for ascertaining the systematic genetic architecture of metric traits within short periods. In the present study, heritability and genetic advance were considered as direct selection parameters, whereas correlation and path coefficient were regarded as indirect selection parameters. The genotypic and phenotypic coefficient of variation is helpful in understanding the clear cut picture of existing variability in the material. Several researchers have also reported earlier the importance of genetic variability and selection parameters for various yield components and quality traits in bread wheat (Singh et al., 2012; Singh et al., 2013, Meena et al., 2014 and Kumar et al., 2016) in the selection of better genotypes of wheat. Hence, in the context of yield improvement, when selecting desirable genotypes it is very important to know the nature and extent of variation present within a set of breeding material as well as the interrelationship between each yield component and grain yield and the exact contribution of each component to yield via direct and indirect effects. It is known that the improvement of the genetic architecture of yield must be based on a more intensive study of individual yield components. Keeping this in view, the present study was undertaken to ascertain the extent of genetic variability, heritability, genetic advance and inter relationship of yield components to establish their implications in the selection of better genotypes of wheat.

\section{MATERIALS AND METHODS}

Ten genotypes of bread wheat (PBW 435, HD 2967, MP 3336, MP 4010, DBW 90, HD 2824, HD 3095, RAJ 4246, NW 5038 and HD 2733) were sown during rabi season 2012-2013 for attempting crossing programme in a $10 \times 10$ diallel fashion excluding reciprocals. In the next crop season rabi 2013-2014, experimental material consisted 55 genotypes (10 parents and $45 \mathrm{~F}_{1} \mathrm{~s}$ ) was sown in a randomized block design with three replications. Each of the parental lines and crosses were sown by dibbling of seeds in two row plot of 2 meter length at spacing of $10 \mathrm{~cm}$ between plants within a row and keeping row to row spacing at $23 \mathrm{~cm}$. All the standard agronomical practices (dose of fertilizer and irrigation at all critical stages) were followed 
to raise normal crop from sowing to till harvest of crop. Observations were recorded on five randomly selected plants in each replication for days to maturity, plant height $(\mathrm{cm})$, number of spikelets per spike, number of grains per spike, 1000 grain weight $(\mathrm{g})$, grain yield (g) and gluten content $(\%)$. The analysis of variance (ANOVA) was based on the model suggested by Panse and Sukhatme, (1967). Heritability (in narrow sense) in $\mathrm{F}_{1 \mathrm{~s}}$ generation was calculated as proposed by Crumpacker and Allard, (1962). The genetic advance was worked out by the formula proposed by Robinson et al. (1949). Genotypic and phenotypic coefficient of variation was calculated by the formula given by Burton and De vane, (1953). The genotypic and phenotypic correlation coefficients were calculated as suggested by Al-Jibouri et al. (1958). In path analysis; direct, indirect as well as residual effects were calculated. All the analysis work was done in Microsoft Excel as per the procedure given by Singh and Chaudhary (1985).

\section{RESULTS AND DISCUSSION}

Analysis of variance: Analysis of variance (Table 2) among all the 55 treatments (parents and their $\mathrm{F}_{1} \mathrm{~s}$ crosses) showed highly significant differences (at $1 \%$ level of significance) for the traits (days to maturity, plant height, spikelets per spike, grains per spike, 1000 grain weight and grain yield) in parents and in hybrids whereas (plant height, spikelets per spike, grains per spike, 1000 grain weight and grain yield) in parents vs. hybrids, indicating the presence of considerable amount of genetic variability in the present set of material and further genetic analysis would be meaningful. Similar findings on the existence of variability were also reported by Singh et al. (2012), Singh et al. (2013), Meena et al. (2014) and Kumar et al. (2016) for different yield and quality traits in wheat crop at different locations in India. The general mean of $\mathrm{F}_{1}$ crosses (Table 5) were greater than their corresponding

Table 1. Pedigree and other details of the parental lines used in crossing programme.

\begin{tabular}{llll}
\hline Parents & Species & Parentage/ pedigree & Origin/Source \\
\hline PBW 435 & T. aestivum & HD 2160/CALIDAD & Ludhiana \\
HD 2967 & T. aestivum & ALD/COC//URES/HD2160M/HD2278 & New Delhi \\
MP 3336 & T. aestivum & HD2402/4W173 & Jabalpur \\
MP 4010 & T. aestivum & ANGOSTURA88 & Jabalpur \\
DBW 90 & T. aestivum & HUW468/WH 730 & Karnal \\
HD 2824 & T. aestivum & PTO-1/CNO79/PRL/GAA/3/HD 1951 & New Delhi \\
HD 3095 & T. aestivum & CPAN300/WR426//HW2007//HD2851 & New Delhi \\
RAJ 4246 & T. aestivum & RAJ 3765/WR544 & Durgapura \\
NW 5038 & T. aestivum & WAXWING*2/VIVITSI & Kumarganj \\
HD 2733 & T. aestivum & ATTILA/3/TUI/CARC//CHENICHTO/4/ATTILA & New Delhi \\
\hline
\end{tabular}

Table 2. Analysis of variance for yield components and gluten content in bread wheat.

\begin{tabular}{|c|c|c|c|c|c|c|c|c|}
\hline $\begin{array}{l}\text { Source of vari- } \\
\text { ation }\end{array}$ & D. F. & $\begin{array}{l}\text { Days to } \\
\text { maturity }\end{array}$ & $\begin{array}{l}\text { Plant } \\
\text { height }\end{array}$ & $\begin{array}{l}\text { Spikelets } \\
\text { per spike }\end{array}$ & $\begin{array}{l}\text { Grains per } \\
\text { spike }\end{array}$ & $\begin{array}{l}\text { Grain } \\
\text { yield }\end{array}$ & $\begin{array}{l}\text { Gluten } \\
\text { content }\end{array}$ & $\begin{array}{l}1000 \text { grain } \\
\text { weight }\end{array}$ \\
\hline Replication & 02 & 0.26 & 0.27 & 0.25 & 0.32 & 1.26 & 0.42 & 3.84 \\
\hline Treatments & 54 & $2.14 * *$ & $31.28 * *$ & $1.14 * *$ & $10.19 * *$ & $9.85 * *$ & 0.16 & $3.58 * *$ \\
\hline Parents & 09 & $4.52 * *$ & $66.84 * *$ & $1.89 * *$ & $13.56^{* *}$ & $7.11 * *$ & 0.23 & $4.75 * *$ \\
\hline Hybrids & 44 & $1.70 * *$ & $22.31 * *$ & $0.88 * *$ & $8.18^{* *}$ & $3.75 * *$ & 0.15 & $2.38 *$ \\
\hline Parents Vs F1s & 01 & 0.16 & $105.46^{* *}$ & $5.96 * *$ & $68.40 * *$ & $302.73 * *$ & 0.18 & $45.96 * *$ \\
\hline Error & 108 & 0.76 & 0.73 & 0.10 & 1.15 & 0.78 & 0.15 & 1.58 \\
\hline Total & 164 & 1.21 & 10.78 & 0.44 & 4.12 & 3.77 & 0.16 & 2.27 \\
\hline
\end{tabular}

*, ** Significant at $5 \%$ and $1 \%$ probability level, respectively.

Table 3. Genotypic and phenotypic correlation for yield components and gluten content in bread wheat.

\begin{tabular}{|c|c|c|c|c|c|c|c|c|}
\hline Trait & $\mathbf{r}$ & $\begin{array}{l}\text { Days to } \\
\text { maturity }\end{array}$ & $\begin{array}{l}\text { Plant } \\
\text { height }\end{array}$ & $\begin{array}{l}\text { Spikelets } \\
\text { per spike }\end{array}$ & $\begin{array}{l}\text { Grains per } \\
\text { spike }\end{array}$ & $\begin{array}{l}\text { Gluten } \\
\text { content }\end{array}$ & $\begin{array}{l}1000 \text { grain } \\
\text { weight }\end{array}$ & $\begin{array}{l}\text { Grain } \\
\text { Yield }\end{array}$ \\
\hline Days to & $\bar{G}$ & 1.0000 & 0.6383 & 0.0967 & -0.0329 & -0.2757 & 0.0346 & 0.0980 \\
\hline maturity & $\mathrm{P}$ & 1.0000 & $0.4217 * *$ & -0.0393 & -0.0189 & 0.0113 & 0.0558 & 0.0118 \\
\hline Plant & G & & 1.0000 & -0.1899 & -0.1548 & -0.8577 & 0.1043 & 0.0954 \\
\hline height & $\mathrm{P}$ & & 1.0000 & $-0.1533 *$ & -0.1301 & -0.1235 & 0.0694 & 0.0809 \\
\hline Spikelets & $\mathrm{G}$ & & & 1.0000 & 0.8754 & 0.5447 & -0.3601 & 0.6355 \\
\hline per spike & $\mathrm{P}$ & & & 1.0000 & $0.6966 * *$ & 0.1316 & $-0.1863 *$ & $0.5247 * *$ \\
\hline Grains per & $\mathrm{G}$ & & & & 1.0000 & 0.9719 & -0.3769 & 0.7726 \\
\hline spike & $\mathrm{P}$ & & & & 1.0000 & 0.0819 & $-0.1739 *$ & $0.6721 * *$ \\
\hline Gluten & G & & & & & 1.0000 & 0.0777 & 1.0000 \\
\hline content & $\mathrm{P}$ & & & & & 1.0000 & -0.0719 & 0.0834 \\
\hline 1000 grain & G & & & & & & 1.0000 & -0.3716 \\
\hline weight & $\mathrm{P}$ & & & & & & 1.0000 & -0.0540 \\
\hline
\end{tabular}

$*, * *$ Significant at $5 \%$ and $1 \%$ probability level, respectively. 
Sandeep Kumar et al. / J. Appl. \& Nat. Sci. 9 (2): 879 - 882 (2017)

Table 4. Direct and indirect effects of component traits on grain yield in bread wheat.

\begin{tabular}{|c|c|c|c|c|c|c|c|c|}
\hline Trait & Path & $\begin{array}{c}\text { Days to } \\
\text { maturity }\end{array}$ & $\begin{array}{c}\text { Plant } \\
\text { height }\end{array}$ & $\begin{array}{l}\text { Spikelets } \\
\text { per spike }\end{array}$ & $\begin{array}{l}\text { Grains per } \\
\text { spike }\end{array}$ & $\begin{array}{c}\text { Gluten } \\
\text { content }\end{array}$ & $\begin{array}{c}1000 \text { grain } \\
\text { weight }\end{array}$ & $\begin{array}{c}\text { Grain } \\
\text { Yield }\end{array}$ \\
\hline Days to & $\mathrm{G}$ & 0.4508 & 0.2877 & 0.0436 & -0.0148 & -0.1243 & 0.0156 & 0.0980 \\
\hline maturity & $P$ & -0.0150 & -0.0063 & 0.0006 & 0.0003 & -0.0002 & -0.0008 & 0.0118 \\
\hline Plant & $\mathrm{G}$ & 0.0457 & 0.0716 & -0.0136 & -0.0111 & -0.0614 & 0.0075 & 0.0954 \\
\hline height & $\mathrm{P}$ & 0.0078 & 0.0186 & -0.0029 & -0.0024 & -0.0023 & 0.0013 & 0.0809 \\
\hline Spikelets & $\mathrm{G}$ & 0.0076 & -0.0149 & 0.0786 & 0.0689 & 0.0428 & -0.0283 & 0.6355 \\
\hline per spike & $\mathrm{P}$ & 0.0000 & 0.0001 & -0.0004 & -0.0003 & -0.0001 & 0.0001 & $0.5247 * *$ \\
\hline Grains per & G & 0.0119 & 0.0560 & -0.3167 & 0.3617 & -0.3516 & 0.1363 & 0.7726 \\
\hline spike & $\mathrm{P}$ & -0.0045 & -0.0308 & 0.1650 & 0.2369 & 0.0194 & -0.0412 & $0.6721^{* *}$ \\
\hline Gluten & $\mathrm{G}$ & -0.0234 & -0.0727 & 0.0462 & 0.0824 & 0.0847 & 0.0066 & 1.2968 \\
\hline content & $P$ & 0.0003 & -0.0037 & 0.0039 & 0.0025 & 0.0300 & -0.0022 & 0.0834 \\
\hline 1000 grain & $\mathrm{G}$ & -0.0058 & -0.0175 & 0.0604 & 0.0632 & -0.0130 & -0.1678 & -0.3716 \\
\hline weight & $\mathrm{P}$ & 0.0026 & 0.0033 & -0.0088 & -0.0082 & -0.0034 & 0.0473 & -0.0540 \\
\hline
\end{tabular}

*,** Significant at $5 \%$ and $1 \%$ probability level, respectively.

Table 5. Genetic parameters for yield components and gluten content in bread wheat.

\begin{tabular}{lcccccc}
\hline Trait & Grand mean & Range & PCV & GCV & Narrow sense (Hb) & GA as \%of means(5\%) \\
\hline Days to maturity & 136.07 & $133.33-137.33$ & 0.81 & 0.50 & 80.5 & 0.63 \\
Plant height & 90.56 & $80.20-95.57$ & 3.65 & 3.52 & 83.5 & 7.01 \\
Spikelets per spike & 17.38 & $16.13-18.73$ & 3.84 & 3.39 & 40.3 & 6.17 \\
Grains per spike & 52.53 & $48.07-55.97$ & 3.88 & 3.31 & 4.88 & 5.80 \\
Grain yield & 21.51 & $16.64-24.23$ & 9.07 & 8.08 & 10.6 & 14.84 \\
Gluten content & 8.53 & $7.87-8.97$ & 4.63 & 0.61 & 15.5 & 0.17 \\
1000 grain weight & 42.75 & $40.90-45.25$ & 3.51 & 1.91 & 9.3 & 2.15 \\
\hline
\end{tabular}

*, ** Significant at $5 \%$ and $1 \%$ probability level, respectively.

parents for (days to maturity, plant height, spikelets per spike, grains per spike, grain yield, gluten content and 1000 grain weight). Present results indicated that the variability in progenies which was obtained through hybridization could be properly utilized for selection of suitable genotypes on the basis of different genetic parameters. Similar findings were also reported by Singh et al. (2012), Singh et al. (2013) and Kumar et al. (2016) in wheat crop at different location of India.

Estimation of variability: Phenotypic coefficient of variation for all the traits was higher than the genotypic coefficient of variation (Table 5) which indicated the influence of environment in the expression of these metric traits. The highest value of phenotypic coefficient of variation (PCV) and genotypic coefficient of variation $(\mathrm{GCV})$ were recorded for grain yield $(\mathrm{PCV}=9.07$ and $\mathrm{GCV}=8.08)$. Whereas remaining traits namely days to maturity, plant height, gluten content, spikelets per spike, 1000 grains weight and grains per spike showed low value of PCV and GCV. Similar findings were also reported by Meena et al. (2014) and Kumar et al. (2016) for grain yield in wheat crop in India. Similar findings were also reported by Singh et al. (2013) for days to maturity, plant height and protein content; Meena et al. (2014) for grains per spike; Kumar et al. (2016) for 1000 grain weight in wheat crop. Present results revealed that useful variability in progenies may be utilized while making selection of suitable genotypes on the basis of different genetic parameters to improve grain yield in wheat.

Heritability and genetic advance: In the present study (Table 5), high heritability in narrow sense (more than $60 \%$ ) was observed for days to maturity (80.5) and plant height (83.5).While for remaining traits like spikelets per spike, grains per spike, 1000 grains weight, gluten content and grain yield were showed moderate to low heritability. Similar findings were also reported by Singh et al. (2012) for days to maturity; Singh et al. (2013) and Meena et al. (2014) for plant height; Emeka et al. (2016) for days to maturity and plant height and Kumar et al. (2016) for spikelets per spike in wheat crop at different locations in India. Highest genetic advance (mare than $10 \%$ ) was recorded for grain yield (14.84) indicating that selection based on grain yield would be effective for improvement of wheat crop. Similar findings pertaining to high genetic advance were also reported by Emeka et al. (2016) and Kumar et al. (2016) for grain yield in wheat crop at different location of India.

Estimates of high heritability coupled with high genetic advance of a character are more effective for making selection due to the fact that expression of these traits is controlled by additive gene action. Highest heritability along with highest genetic advance was recorded for grain yield $\left(\mathrm{h}^{2}=10.6\right.$ and $\left.\mathrm{GA}=14.84\right)$ revealing the presence of additive and additive $\mathrm{x}$ additive type of gene effects in the expression of grain yield. Likewise, high heritability coupled with high genetic advance was also reported by Singh et al. (2012) and Kumar et al. (2016) in wheat. Therefore, present results indicated that useful variability in progenies developed through hybridization can be properly utilized and selection of suitable genotypes on the basis of different genetic parameters can be done to get high yield and 
gluten content in bread wheat.

Correlation coefficient: A close relationship between genotypic and phenotypic correlations (Table 3) in most of the traits indicating low environmental effects on the degree of association between various yield components. Genotypic correlation coefficients were, in general, slightly higher than the corresponding phenotypic correlation coefficient for almost all the traits under study. The improvement of yield components and the knowledge of their association with its main component are beneficial in formulating the breeding programme. Correlation coefficients were estimated between grain yield and other component traits revealed that grain yield was highly significant and positively associated with number of grains per spike ( $\mathrm{gr}=0.77$ and $\mathrm{pr}=0.67$ ) and number of spikelets per spike ( $\mathrm{gr}=0.63$ and $\mathrm{pr}=0.52)$ at both genotypic as well as phenotypic level (Table 3 ) indicating that grain yield and these traits has the same physiological basis for their expression. Similar findings of correlation coefficient were also earlier reported by Meena et al. (2014) and Kumar et al. (2016) for spikelets per spike and grains per spike in wheat crop at different locations of India. Positive association between spikelets per spike and grains per spike was reported by Meena et al. (2014) in wheat crop. It has been observed that number of grains per spike and number of spikelets per spike were positively associated with grain yield. Hence, selection for these traits would also helps in improving grain yield. In the present investigation, the traits which exhibited direct positive correlation with grain yield may be considered as most important traits combinations for yield improvement in bread wheat through selection.

Path coefficient: In path coefficient analysis, selection may be done on the basis of direct effects of the components traits towards grain yield for improvement of wheat crop. The results of path coefficient (Table 4) indicated that three yield traits (gluten content, grain per spike and plant height) showed positive phenotypic and genotypic direct effects on grain yield whereas, rest of the traits showed negative direct effect on grain yield. Present finding were similar to the findings of Kumar et al. (2016) for days to maturity, grain per spike and plant height at different locations of India in wheat.

\section{Conclusion}

Based on the above results, it may be concluded that grain yield in wheat crop showed highest heritability with highest genetic advance and also have highest PCV and GCV therefore selection will be effective based on grain yield due to the maximum contribution of additive gene action. Spikelets per spike and grains per spike showed positive significant correlation and also have positive direct effects on grain yield at both genotypic as well as phenotypic level, indicating that we might improve grain yield by improving these traits and thus emphasis should be given on these traits for the selection of elite genotypes from the segregating generations. It is evident that genotypes developed might serve as good source of material for further breeding programme.

\section{REFFERENCES}

Al-Jibouri, H. A., Miller, P. A. and Robinson, H. F. (1958). Genotypic environment variances in an upland cotton cross of inter-specific origin. Agronomy Journal, 50: 633-637

Anonymous, (2016). Progress Report of all India Coordinated Wheat and Barley Improvement Project, 1-5 pp G. P. Singh (Ed). Directorate of Wheat Research, Karnal.

Burton, G. W. and De Vane, E. W. (1953). Estimating heritability in tall fescue (Festuca arundinacea) from replicated clonal material. Agronomy Journal, (45): 478-481

Crumpacker, D. W. and Allard, R. W. (1962). A diallel cross analysis of heading date in wheat. Hilgardia, 32: 275318

Emeka, C. O., Christain, U. A., Michael, I. U. and Francis, C. O. (2016). Germplasm evaluation of heat tolerance in bread wheat in Tel Hadya, Syria. Chilean Journal of Agricultural Research,76 (1): 9-17

Kumar Pradeep, Gyanendra Singh, Sarvan Kumar, Anuj Kumar and Ashish Ojha (2016). Genetic analysis of grain yield and its contributing traits for their implications in improvement of bread wheat cultivars. Journal of Applied and Natural Science, 8(1): 350-357

Meena, H. S., Kumar, D. and Prasad, S. R. (2014).Genetic variability and character association in bread wheat (Triticum aestivum). Indian Journal of Agricultural Sciences, 84 (4): 487-91

Panse, V. G. and Sukhatme, P. V. (1967). Statistical Methods of Agricultural Workers. 2nd Endorsement, ICAR Publication, New Delhi, India, Pp: 381

Robinson, H. F., Comstock, R. E. and Harvey, P. H. (1949). Estimates of heritability and degree of dominance in corn. Agronomy Journal, 41: 353-359

Singh, M. K., Sharma, P. K., Tyagi, B. S. and Singh, G. (2013). Genetic analysis for morphological traits and protein content in bread wheat (Triticum aestivum L.) under normal and heat stress environments. Indian Journal of Genetics and plant breeding, 73 (3): 320-324

Singh, R. K. and Chaudhary, B. D. (1985). Biometrical methods in quantitative genetic analysis. (3rd Ed.), Kalyani Publishers, New Delhi, India.

Singh, V., Krishna, R., Singh, L. and Singh, S. (2012). Analysis of yield traits regarding variability, selection parameters and their implication for genetic improvement in wheat (Triticum aestivum L.). SABRAO Journal of Breeding and Genetics, 44 (2): 370-381 